\title{
RAZONES Y SINRAZONES DEL INFANTICIDIO DE MEDEA
}

\author{
R. Verónica Peinado Vázquez ${ }^{1}$ \\ Centro de Investigación y Docencia en Humanidades \\ Estado de Morelos, México
}

Resumen: El infanticidio cometido por Medea en la Tragedia de Eurípides ha sido catalogado como un acto criminal en el que la razón y las argucias de la protagonista juegan un papel importante. Dichos componentes han sido reiterados a partir del significado del nombre propio de Medea. En este ensayo se revisará dicho nombre propio pero a través del análisis del significante, para apreciar los elementos - tanto los claramente lógicos como aquellos propios de la locuraque condujeron a Medea a cometer el asesinato de sus hijos.

Palabras clave: Medea, Eurípides, infanticidio, narcisismo, locura

\section{Reason and Unreason of the infanticide of Medea}

\begin{abstract}
The infanticide committed by Medea in the Tragedy of Euripides is classed as a criminal act where the reasons and ruses of the protagonist play an important role. These components were traditionally studied from the signified of the name of Medea. In this essay we also studied her name but from the analysis of the signifier to look the elements (the rational and insane motivations) who drive Medea to commit the murder of her children.
\end{abstract}

Keywords: Medea, Euripides, infanticide, narcissism, madness

\section{Introducción}

Existen obras de la literatura universal que han atraído la atención de innumerables lectores, sea por su optimismo y belleza, sea por su crudeza y verdad. El personaje de Medea ha gozado de gran fama a través de los tiempos. $\mathrm{Ha}$ interesado por igual a poetas, pintores, músicos, etc., e incluso su leyenda es conocida por toda persona medianamente cultivada. La Medea se considera la obra maestra de Eurípides; fue representada en el año 431, componiendo una tetralogía con Filoctetes, Dictis y el drama de sátiros Los recolectores. Nuestro poeta obtuvo con ella el tercer/último lugar, quedando atrás, en esa ocasión, de Euforión y Sófocles.

Fueron los poetas latinos los primeros en retomar las obras de Eurípides para su recomposición, a partir de ellos surgió un gran número de imitadores o adaptadores de la tragedia que aquí nos ocupa, además de una cantidad nada

\footnotetext{
${ }^{1}$ Dra. en Letras por la Universidad Nacional Autónoma de México. Catedrática del Seminario de Cultura griega del Posgrado en Literatura del Centro de Investigación y Docencia en Humanidades del Estado de Morelos, México.
} 
despreciable de estudios especializados al respecto, sobre todo en el último siglo. El presente artículo tiene como objetivo presentar un análisis del infanticidio cometido por Medea a partir de las razones y sinrazones de la protagonista, mostrando que los actos criminales pertenecen al ámbito de la locura y que, por terribles que sean, presentan una verdad.

\section{EL MYTHOS}

Medea no es un "personaje literario", pues, como bien sabemos, los trágicos se basaban, para la elaboración de su argumento dramático, en historias de la tradición oral conocidas por el público. La historia de Medea comienza con la aparición de Jasón en su expedición con los argonautas. El héroe es enviado, por orden de Pelias, rey de Yolco, a la Cólquide con el fin de apoderarse del vellocino de oro que pertenecía a Eetes, rey de esa región y padre de Medea.

Pero Eetes, no queriendo entregar el toisón, le impone a Jasón como prueba vencer a los toros de Hefesto y a una serpiente, condición de la cual, estaba seguro, no saldría vivo. Entretanto, Medea, que se había enamorado del extranjero y utilizando sus dotes de maga, le ayuda a salir victorioso de la pelea con tales seres. Así Jasón logra obtener el preciado botín. Una vez culminada la empresa, Medea huyó en la nave Argos con Jasón, quien le había prometido matrimonio a cambio de su ayuda. Con el fin de que su padre se retrasara en la persecución que emprendió, Medea había decidido llevar, como rehén, a su hermano menor (Apsirto) a quien despedaza y arroja al mar, con el fin de que Eetes se demore recogiendo los trozos del cuerpo de su hijo.

En lo referente al matrimonio de los fugitivos, existe una tradición tardía que indica que Jasón se había casado en la misma Cólquide y había vivido allí cuatro años antes de iniciar las proezas para conseguir el preciado toisón. Pero la versión anterior indica que el matrimonio no se realizó inmediatamente sino que cuando, en su huida, llegó al país de Alcinoo, Medea se enteró de que el rey estaba dispuesto a entregarlos al padre; aunque no lo haría en el caso de que ella ya no fuera virgen. Para salvarla y salvarse, Jasón acepta desposarla.

Continuando el viaje, llegan a Yolco, de donde Jasón y los argonautas habían partido. Medea, para vengarse de Pelias, quien había ordenado a Jasón la peligrosa empresa, convenció a sus hijas de que era capaz de rejuvenecer a cualquier ser humano toda vez que lo hubiera hervido en una poción mágica.

Las jóvenes, siguiendo sus instrucciones, lo despedazaron y lo lanzaron a un caldero del que nunca salió. Arcasto, hermano de las muchachas, desterró del reino a Jasón y Medea.

Es así como llegaron a Corinto, en otros tiempos reino del padre de Medea, donde fueron admitidos por el rey Creonte. Esta información era conocida en la tradición oral, Eurípides la da por sabida y no se detiene en los elementos previos al desarrollo de su historia. 


\section{El argumento trágico de Eurípides}

Después de algunos años de unión y la procreación de dos hijos, dio inicio el problema que Eurípides nos relata en la tragedia Medea. El rey Creonte quiso casar a su hija con Jasón, y éste no se rehusó a tal petición. Creonte decretó el destierro de Medea, a quien temía y consideraba enemiga, pero ella, valiéndose de su poder persuasivo, consiguió aplazar un día la orden, para así poder llevar a cabo su venganza contra el rey, su hija y Jasón.

Aprovechando nuevamente su condición de maga, Medea impregnó veneno en un vestido, adornos y joyas y envió a sus niños a entregar los obsequios a la princesa, quien, al ponérselos, fue abrasada enseguida por el fuego que se produjo del contacto del veneno con su piel. Su padre, al acercarse a auxiliarla, muere de la misma manera.

Después de esto, Medea asesina a sus propios hijos y se marcha a la tierra de Egeo, quien le había prometido asilo.

\section{La variante de Eurípides}

La reputación del personaje de Medea se lo debemos a la variante literaria introducida por Eurípides, pues recordemos que si bien la literatura griega se nutría de las historias provenientes de la tradición oral, el autor elegía una variante existente o introducía una nueva. Existían por lo menos dos variantes relativas al infanticidio cometido por Medea. En la primera, se decía que los niños, considerados culpables al ser los portadores del regalo que ocasionó la muerte de la princesa y Creonte, a pesar de que desconocían los planes de su madre y sólo obedecieron órdenes, fueron apedreados por los corintios que vengaban la muerte de su princesa y su rey. En la otra, Medea es quien asesina a sus propios hijos, sin embargo, su acción estaba de alguna manera justificada, ya que la diosa Hera se lo había ordenado, prometiendo a cambio la inmortalización de los mismos y un culto en la ciudad. Eurípides nos ofrece una variante a este hecho, que es el que marca la singularidad de su obra: la muerte de los hijos a manos de su madre, con el único propósito de castigar al desleal marido.

\section{MEDEA: NADIE}

Los estudios más recientes en torno a la obra de Eurípides hacen énfasis en los factores sociales que son denunciados por sus personajes e historias; la obra de Eurípides refleja la crisis o "desorden del oikos" que en su propia época imperaba. La situación de Medea evidencia un mundo donde existen categorías de personas, entre las cuales unas tenían más valor que otras, según las reglas morales que dictaba la sociedad. En el análisis de la tragedia Medea estos factores sociales, como detonadores del infanticidio, son evidentes. Dichos factores se resumen, por cierto, en el análisis lingüístico del nombre de la protagonista. 


\section{a. El nombre propio}

El núcleo de la identidad no reside ni en la imagen del cuerpo ni en el real de la carne sino en el nombre propio. ${ }^{2}$

Ha sido el psicoanálisis, constituido a partir de los aportes de Jacques Lacan, el que ha señalado la enorme importancia que posee el nombre propio en la configuración de la estructura subjetiva. En el seminario titulado La identificación, Lacan investiga acerca del núcleo de la identidad y se da cuenta, siguiendo las tesis de Jakobson ${ }^{3}$, que tal identidad no reposa ni en la imagen corporal (el imaginario) ni en su sustrato real (eso que podría denominarse "la carne") sino que se encuentra sustentado en el nombre propio (Identificación). Lacan indica que la identidad reposa en el nombre propio y que ese nombre propio contiene una carga, es decir, tanto los orígenes de la familia que están indicados en el apellido así como la elección del nombre de pila o incluso el mote del sujeto, portan una cantidad de rasgos que aquel que lleva el nombre habitualmente ni siquiera sospecha (aunque los actúa inconscientemente) ${ }^{4}$.

Los griegos no eran ajenos a esta cuestión y reiteradamente encontramos el uso deliberado de "nombres parlantes" en la literatura. La introducción a este campo de la filología es el que permitirá arrojar las claves que se revisarán en el presente trabajo, pues la resonancia del nombre de Medea contiene las razones que conducen la historia literaria.

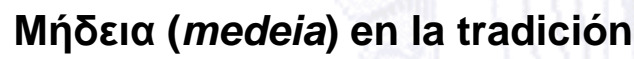

Por lo anteriormente expuesto, lo primero que de la persona de Medea nos interesa es el nombre. Los eruditos se inclinan por conjeturar la traducción de

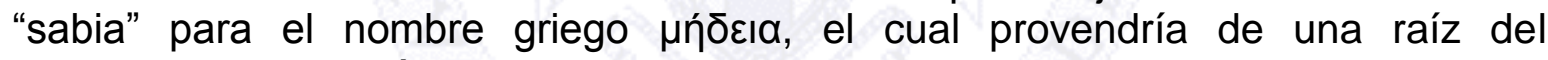
indoeuropeo *md, raíz que designa toda actividad propia de la mente, y de donde

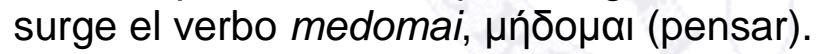

De su antiguo carácter la Medea de Apolonio apenas conserva algo más que su nombre parlante: Mńठદı “la Sabia" (Taccone 1938:9 por Gil Fernandez 1971, p.119).

La traducción de "sabia" que se concede a la protagonista es en el sentido del dominio de una réXvn (téjne): en el caso de Medea se aplica dado sus dotes en el arte de la magia y de la persuasión y no en el sentido moral. Esta interpretación, generalizada, se basa principalmente en el hecho de que Medea consigue llevar a cabo su plan de venganza gracias a que convence al rey Creonte de que le

\footnotetext{
${ }^{2}$ Luis Tamayo, Diplomado "Lacan con Heidegger", FFyL de la UNAM, 2006.

${ }^{3}$ En su libro Elementos de lingüística, utiliza el ejemplo del "tren de las diez y media"; en dicho ejemplo la pregunta es ¿cuál es el tren de las diez y media? No es el de la marca Mercedes Benz ni el color azul o negro, es decir, su sustrato real puede cambiar, la imagen puede cambiar, lo único que se conserva es el nombre: es "el tren de las diez y media".

${ }^{4}$ Encontramos ejemplos de ello en los estudios. Marguerite ou l'Aimée de Lacan de J. Allouch (EPEL, 1990) y Ernst Wagner de A.M. Vindras (EPEL, 2000).
} 
permita quedarse en Corinto un día más, fingiendo inocencia y debilidad, y aprovechando sus saberes mágicos para impregnar con venenos los regalos de la princesa.

Medea: [...] siendo sabia, a unos les resulto odiosa; a otros, indolente; a otros, de temperamento contrario; para otros, en fin, molesta. (v. 303)

La sabiduría de Medea reside, entonces, en la posesión de una téjne:

Medea: lo mejor es la vía directa, en que, de nacimiento, soy extraordinariamente sabia: vencerlos con mis venenos. (383)

Jasón presume que es gracias a él que esa cualidad de Medea se conoce:

Jasón: Por haberme salvado, has recibido más de lo que diste [...]. En primer lugar, habitas una tierra helena en vez de un territorio bárbaro, has aprendido justicia y a servirte de leyes, sin favorecer la violencia. Todos los helenos se enteraron de que eres sabia y adquiriste renombre. Si habitaras en remotos confines, no existiría tu prestigio. (540)

Sin embargo, hay que notar que el término griego para designar en estos pasajes la cualidad de sabia de Medea es oọós ,ń (sofós,e), pues, como ya señalamos, no existe el adjetivo derivado de la raíz *md con tal connotación. Esta interpretación del nombre de Medea no permite, sin embargo, profundizar en la tragedia de Eurípides y el acto homicida que ahí se muestra. Proponemos otras posibilidades de escuchar lo que el nombre de nuestra protagonista dice, que nos conducen a reflexionar y entender los sucesos que se desarrollan en esta tragedia.

\section{La resonancia}

Bajo el título Fobia con nombre propio, Jean Allouch narra la siguiente anécdota ocurrida en el consultorio del famoso psicoanalista Jacques Lacan:

J.M. Ribettes menciona, en ocasión de su primera entrevista preliminar, tal fobia suya de animales. Lacan destaca la cosa, y de la manera siguiente:

-Es un hecho: las bettes (bestias) que lleva su nombre no le hacen reír ( $r i)$.

Es éste un magnífico ejemplo de lo que el nombre propio puede indicar, aunque de manera inconsciente, a aquel que lo lleva y, en este caso específico, la indicación se da por un fenómeno lingüístico al que llamaremos "resonancia" (siguiendo uno de los significados del diccionario: "sonido producido por repercusión de otro"), es decir, un sonido que produce la escucha de otro sonido. Es un fenómeno fonético que ocurre en la lengua y que se presenta cuando una palabra, o unión de palabras en una frase, ocasiona un sonido que cambia la semántica de dicha palabra o frase; es decir, ciertas palabras "suenan", "se oyen" de tal manera que remiten a otros significantes. La resonancia nos remite al vocablo "significante" utilizado en el sentido admitido por Saussure en el Curso de lingüística general (1993, p. 103), en donde indica: "Llamamos signo a la combinación del concepto y de la imagen acústica". [...] "Nosotros proponemos 
conservar la palabra signo para designar la totalidad, y reemplazar concepto e imagen acústica respectivamente por significado y significante". Y es menester agregar la indicación de Saussure (1993, p. 108): "[...] los significantes acústicos no disponen más que de la línea del tiempo; sus elementos se presentan uno tras otro; forman una cadena". Es decir, un significante siempre remite a otro significante, lo cual da como resultado el lenguaje, con lo cual cambiamos el sentido de la palabra pronunciada: vgr. es común, en nuestra cultura mexicana, burlarse del nombre extranjero Sergei, pues nos remite a "ser gay". Y, en el ámbito del cine hollywoodense tenemos un ejemplo claro de la resonancia: Rain Man, película en la cual un hombre con problemas de lenguaje mostraba una fobia a la Iluvia. Su nombre real era Raymond, nombre que su hermano menor pronunciaba de tal manera que le hizo escuchar Rain man ("hombre lluvia").

La resonancia del nombre propio es, casi siempre, inconsciente, aunque, como lo indicamos, ello no le impide ser actuada.

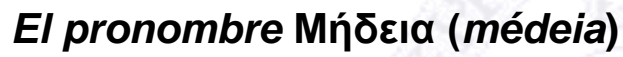

Como ya señalamos, no existe la palabra $\mu$ ńঠદı (médeia) con significado propio sino que se deduce el significado "sabia" a partir de un verbo que sí existe en la lengua griega. Pero existe en griego un vocablo que se escribe y se escucha

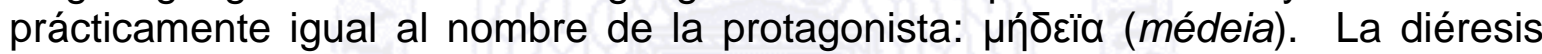
separa el diptongo $\varepsilon і ̈$ en $\varepsilon$-ı. Es la forma poética de un pronombre indefinido

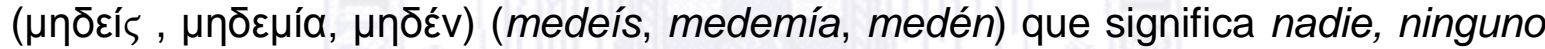
(a), nulo (a), sin importancia.

Este significado resume la situación social de Medea que revisaremos en el siguiente apartado: Medea era una extranjera, por lo tanto sin ningún valor en la sociedad corintia; era mujer, condición en general ínfima en el mundo griego, y dentro de esa condición ni siquiera era considerada esposa legítima de Jasón. Es decir, era nadie, por lo menos dentro de la sociedad corintia. Esta resonancia solo pudo hacerse efectiva cuando su contexto y situación se hicieron patentes ante el nuevo casamiento de Jasón. Pues recordemos que Medea en su tierra era una princesa, hija del rey Eetes.

La venganza llevada a cabo por Medea cobra sentido: alcanzar la fama y dejar atrás lo que su nombre le decía.

Pero existe otro término griego que tiene semejanza fonética con el nombre de la protagonista y que también aporta a la comprensión de los actos de Medea.

\section{El sustantivo $\mu n ́ \delta \varepsilon \alpha$ (médea)}

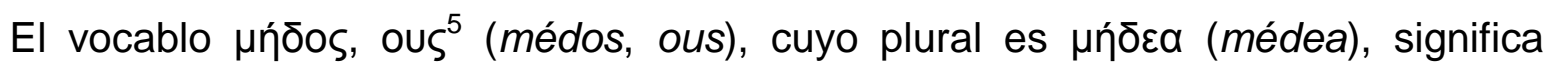
"pensamiento, resolución, designio de los dioses"; la primera y segunda acepción nos remite al carácter de racionalidad que Medea exhibe al llevar a cabo su plan

\footnotetext{
${ }^{5}$ También dela raíz indoeuropea *md que designa actividad del pensamiento.
} 
de venganza. El último concepto, por su parte, tiene particular importancia, pues, en la tragedia que aquí nos ocupa, Medea hace constantes alusiones al apoyo de los dioses para cometer su venganza, dado que los colocaba como testigos del incumplimiento de los juramentos hechos por Jasón, además su linaje divino, al cual también hace referencia repetidamente, no es un factor menor para el infanticidio. En la resonancia del sustantivo $\mathrm{mh} / \mathrm{dea}$ la venganza de Medea también fue de los dioses.

De idéntica forma es el plural $\mu n ́ \delta \varepsilon \alpha$ (médea) (no se usa en singular) que significa "miembro viril". Esta posibilidad también es coherente con lo que Medea nos transmite en la obra, y particularmente con el asesinato de sus hijos, ya que el "carácter masculino", aseguran los analistas del infanticidio, es muy fuerte en ella y es el causante de que Medea se atreviera a cometer tal acto.

La conjunción de las tres resonancias son las que marcan el comportamiento y acciones de Medea: su orgullo, su pasión, su deseo de venganza y, por último, el infanticidio.

\section{b. Los factores sociales}

Si bien la peor situación que envuelve la vida de un criminal no justifica sus actos, sí nos conduce a entender las razones ahí presentes, la verdad que se muestra en cada crimen.

\section{La mujer en Grecia}

Ahora no soy nada y me dejan sola; a menudo he observado que éste es el destino de la mujer: no ser nada.

Sófocles ${ }^{6}$

El término para designar a la mujer (joven soltera o casada) en griego se dice үuvń/ (guné), de la raíz *gn de donde se deriva también el verbo yíyvouaı (gignomal), que significa nacer, engendrar, llegar a ser, con lo cual yuvń (guné), en su significado etimológico, quiere decir engendradora, la que tiene hijos.

Aunque todas las mujeres podían tener hijos, no a todas ellas se les reconocía como madres honorables, cuyos descendientes pudieran tener el privilegio de ser reconocidos por el padre. La explicación es muy simple: en Grecia estaban bien delimitadas las funciones y derechos de la mujer dependiendo de la categoría a la que perteneciera: Había tres categorías de mujeres: hetairai, pallakai, y gynaikes, es decir, cortesanas, concubinas y esposas respectivamente, su función, como queda clara en la referencia de Demóstenes, estaba delimitada: las cortesanas están para el placer, las concubinas para las necesidades cotidianas, las esposas para tener descendencia legítima y ser fieles guardianas del hogar.

Las esposas eras las mujeres unidas a varones ciudadanos a través de engye (promesa de matrimonio, desposorio), y cuyos hijos eran legítimos. Mientras que

\footnotetext{
${ }^{6}$ Tereus, frag. 524, Nauck.
} 
las cortesanas estaban dedicadas a proporcionar placer y las concubinas se ocupaban del servicio personal diario del varón, la esposa tenía a su cargo una función más trascendente: además de velar por los bienes del marido, era la encargada de engendrar a los hijos, responsabilidad que tenía principalmente ante su esposo, luego con los dioses y con la sociedad en general. Su función era clara: el cuidado del oikos en el matrimonio y la procreación. De ello da cuenta Jenofonte en el Económico, donde hay constantes referencias a la labor de la mujer casada: debe saber hacer vestidos, señalar a las sirvientas sus tareas, etc.

\section{El matrimonio}

Aunque el matrimonio como institución no existía, había un procedimiento o una ceremonia a seguir que es la que determinaba su legitimidad. El término griego que refiere la unión es engye (término que remite a la promesa de matrimonio o al desposorio mismo) o epidikasia (reclamación). Para indicar que una persona estaba casada se utilizaba la palabra synoikein (compartir una casa).

El hombre griego podía tener, simultáneamente, dos mujeres, una concubina y la esposa legítima, sin que esto fuese considerado un engaño o un acto ilegal. Por lo tanto, no podemos hablar de infidelidad masculina en la Grecia antigua. La mujer sabía que el hombre no le pertenecía, pero cuando quien mantenía relaciones extramaritales era la mujer, entonces sí se consideraba que había adulterio.

Esto no significaba que todas las esposas aceptaran tal hecho, ante nuestra mirada moderna injusto. Este asunto fue tratado ampliamente en la tragedia, especialmente en la de Eurípides, aunque ya Sófocles nos presenta a una Deyanira inconforme por tener que compartir a Heracles con una esclava tomada como botín de guerra. Por eso intentará conquistar de nuevo el amor de su esposo haciendo que éste vista una túnica que ella cree recubierta con un filtro de amor, con las trágicas consecuencias que todos conocemos.

\section{Los hijos}

En la sociedad griega los hijos representaban la consecuencia necesaria de un matrimonio, y casi siempre el objetivo de este último. Entre los griegos, los descendientes tenían funciones determinadas: eran quienes se encargarían de cuidar el oikos y quienes estaban obligados a cuidar de los padres una vez que estos hubieran envejecido. Platón (Leyes, VI, 773), considera la procreación como el cumplimiento de un deber para con los dioses; se consideraba que el ciudadano había de dejar hijos que sirvieran y veneraran a los dioses. También se tenía como un deber moral asegurar la continuidad de la existencia del Estado con la procreación de descendientes.

Cuando señalamos que los hijos eran importantes para el padre, en cuanto que representaban la perpetuación del nombre y la familia, nos referíamos a los hijos legítimos, pues los griegos distinguían entre los hijos legítimos (үvńoıo, gnesioi) y los bastardos (vóӨoı, nothoi). Estos últimos, nothoi, eran hijos de esclavas, prostitutas, madres extranjeras o mujeres bajo un régimen de concubinato. 


\section{Los extranjeros}

En primer lugar, los griegos distinguían entre los extranjeros que llegaban de otra parte pero del mismo territorio heleno (ל́́vos, xenos) y aquellos que venían de otras latitudes (ßápßapo, barbaroi). El término "bárbaro", como ha sido documentado por Manuel García Sánchez en el ensayo Los bárbaros y el Bárbaro: identidad griega y alteridad persa, no poseía en principio sentido despectivo y hacía referencia a una peculiaridad en la pronunciación de la lengua, dicho sentido fue producto de la tragedia y su intención de fortalecer la identidad griega.

Algunos estudiosos indican que Eurípides se atrevió a presentar el infanticidio cometido por Medea precisamente porque ésta era una extranjera bárbara, ya que, aseguran, hubiera resultado inconcebible para el público de la tragedia que una griega, es decir, "civilizada", hubiera cometido un crimen de esa naturaleza. Jasón mismo lo señala en la obra:

Jasón: no hay mujer griega que se hubiera atrevido a esto. (v. 1339)

Una vez en las ciudades griegas, los extranjeros pertenecían a diferentes categorías. En Atenas, había extranjeros de paso y extranjeros definitivamente instalados, llamados metecos quienes habían obtenido el derecho de domicilio. El meteco tenía un prostata, que fungía como intermediario entre él y la ciudad. El prostata de Jasón y Medea era Creonte.

Los derechos de los extranjeros al interior de la ciudad eran muy limitados (Glotz, 223), y sólo los metecos podían aspirar a gozar de ellos. Dos de estos derechos son la isotelia y la proxenia, relacionados sobre todo al aspecto económico, sin embargo este derecho representaba un honor. Entre los isoteles y los ciudadanos estaban los proxenies, es decir los nuevos ciudadanos, aquellos que habían obtenido este título por decreto del pueblo. La proxenia es, entonces, el derecho a la ciudadanía. Este derecho, sin embargo, se restringía dependiendo de otras circunstancias de tipo económico, pues en época de crisis el alimento se distribuía equitativamente entre los ciudadanos.

\section{$\star \star \star$}

El matrimonio de Medea y Jasón, si ocurrió —recordemos las versiones de la leyenda que indican que se casaron en tierra de Medea o que fueron obligados a ello durante su persecución, y en la tragedia de Eurípides no hay claridad-, no contó con los requisitos que lo validaran como legítimo, por ello es viable la petición que el rey Creonte hace a Jasón de que despose a su hija. Medea no era más que la concubina. Por lo tanto, los hijos de Medea y Jasón eran, dado el matrimonio ilegítimo o concubinato de sus padres, hijos bastardos.

Los hijos de Medea no podían esperar un futuro promisorio, y con un decreto de concesión de ciudadanía tan restringido -en la época de representación de esta tragedia sólo era ciudadano aquél que había nacido de madre y padre ciudadanos - su futuro no era halagüeño, Jasón lo sabía. 
Las circunstancias histórico-sociales de la Grecia en la que Eurípides representó la tragedia Medea son un elemento clave para comprender el infanticidio y nos conducen a reflexionar sobre la verdad implícita en los actos criminales. La situación de Jasón, Medea y sus hijos no era favorable en tierra corintia, sin embargo, el infanticidio, es decir, el "pasaje al acto" criminal cometido por Medea pertenece solamente al terreno de la locura.

\section{EL INFANTICIDIO}

Jasón lanza ahora nieve a la semilla germinada

Paul Celan (1981, p.28)

Medea: si quieres llámame Escila que vive en suelo tirreno, porque, tal como era necesario, herí tu corazón. (v. 1358)

En la mitología griega el asesinato de los propios hijos era la expresión más terrible de la locura enviada como castigo divino (cfr. Ruth Padel, 2005, p. 21). Sin embargo, en la variante de Eurípides, Medea asesinó a sus hijos de una manera que se ha considerado premeditada, consciente y racional, lo cual la ha convertido en el símbolo del mal. Esta diferenciación entre un asesinato cometido bajo los influjos de la locura y otro que no lo es sigue ocasionando controversia en el ámbito de la justicia penal.

Para Jasón mismo, el infanticidio cometido por Medea es un mero acto criminal ( ovía, fonia, v. 1390), sin embargo, como veremos, no por ello está exento de los elementos propios de la locura, mostrando que la disyuntiva crimen-locura no es fácilmente sostenible.

\section{a. El plan}

Luego de enterarse del nuevo matrimonio de Jasón con la princesa, Medea, según refiere la nodriza, se encuentra mal, consumida por el dolor. Igualmente, desde el inicio de la obra, la nodriza intuye que su ama no se quedará tranquila con el nuevo matrimonio de Jasón:

Nodriza: temo que urda alguna sorpresa, pues violento es su ánimo y no tolerará ser menospreciado. Yo la conozco y tengo miedo de que se clave un afilado puñal en el hígado, tras entrar silenciosamente en casa, donde está tendido su lecho, o que mate al rey y al que se ha casado, y se atraiga, después, alguna desgracia peor, pues terrible es ella. (v. 36)

Y más adelante, luego de enterarse que el rey ha decretado el exilio de Medea, señala:

Nodriza: no cesará en su cólera, lo sé con certeza, hasta haberla lanzado contra alguien. ¡Ojalá les haga algo a sus enemigos, que no a sus amigos! (v. 92) 
Una vez que Creonte acude a Medea para anunciarle la resolución de expulsarla de su reino, ésta empieza a maquinar su venganza, que incluye a la princesa, al rey y a Jasón. La misma Medea se sorprende de que Creonte le concediera permanecer un día más en tierra corintia, pues tiene pensado ocasionar terribles males:

Medea: [...] él ha llegado a tal extremo de locura, que, siéndole posible paralizar mis planes con expulsarme del país, me ha permitido quedarme durante el día de hoy, en que convertiré en cadáveres a tres de mis enemigos: al padre, a la hija y a mi esposo. (v. 371)

Después de esto, se encuentra con Jasón y Medea le comunica su intención de enviar a la princesa unos regalos como señal de buena voluntad. Jasón quiere impedirlo con el argumento de que una princesa lo tiene todo. Medea lo convence y envía el vestido y la corona envenenados.

Como podemos observar, Medea tiene en mente un plan de venganza en el que, en un principio, sus hijos no figuraban.

\section{b. La víctima}

Lo más significativo, en un crimen, es el sujeto que se elige para ser "sacrificado". Medea deseaba vengarse y para ello pudo matar a Jasón, o a la princesa y al rey, tal como lo hizo, o a los tres: en el verso 380 Medea declara abiertamente sus planes de matar a la princesa y al rey, planes que tienen como origen no el abandono de Jasón, sino el decreto del exilio. Sin embargo, incluyó en su venganza el asesinato de sus hijos, dejando con vida a Jasón mismo. La muerte de la princesa podría entenderse, pues, más que por haberse atrevido a despojarla del amor de su pareja — pues quien había elegido a Jasón como su esposo era el padre - porque con su muerte terminaba con cualquier posibilidad de que el traidor gozara de los beneficios de un vástago:

Medea: ni verá de ahora en adelante a los hijos vivos que de mí tuvo, ni engendrará niños de su nueva esposa. (v. 803)

Recordemos que los hijos tenían la responsabilidad de velar por sus padres en la vejez, así como proporcionar un sepulcro digno en su muerte, de manera que la procreación era el objetivo último del matrimonio, al grado tal que la falta de ellos era causal para el divorcio.

Se ha reflexionado mucho sobre el momento en el cual Medea concibió a sus hijos como otra de las víctimas de su venganza contra Jasón. Sin duda, las palabras de otros personajes de la obra contribuyeron a dar forma a tal idea.

\section{El aporte de los otros}

Las ideas no surgen de la nada, es el contexto conformado por los actos/discurso de los otros lo que ayuda a configurar el pensamiento. Los estudiosos de la tragedia Medea han puesto especial cuidado en determinar el momento en el que 
por primera vez Medea considera, como parte de su venganza, la muerte de los niños.

Desde el principio de la obra, sus intenciones, no conocidas por nadie, son previstas por la Nodriza, quien puede intuir que el daño alcanzará también a los niños, y, por ello, dice al pedagogo:

Nodriza: tú, cuando los hayas alejado lo más posible, cuídalos, y no los acerques a su madre abatida. Pues ya le vi una mirada de toro contra ellos, como proponiéndose algo. (v. 90)

Sin embargo, la nodriza comprende que, ante una traición como la que sufrió su ama, no es fácil sosegarse:

Nodriza: no hay modo de que mi señora aplaque su cólera con algo insignificante. (v. 171)

El odio que, efectivamente, surge tempranamente contra los hijos, se refleja en el deseo, pero simple deseo, de que mueran:

Medea: malditos hijos de odiosa madre, ojalá mueran con su padre, y toda la casa perezca. (v. 113)

Más adelante, en el diálogo con Creonte, cuando éste remarca que sus hijos son lo más querido para él, Medea pudo concebir la idea:

Creonte: Tengo miedo de que tú hagas a mi hija algún daño irreparable. (v.282)

Y cuando Medea muestra la nostalgia por su patria, Creonte responde:

Realmente excepto mis hijos, también para mí es lo más querido. (v. 284)

El encuentro con Egeo, con quien Medea sostuvo una charla acerca de la descendencia, y a quien prometió, con sus dotes de maga, curar de la infertilidad que lo aquejaba no fue solo para señalar el futuro que le deparaba a Medea, quien sería acogida por este rey, sino para contribuir al tema de los hijos:

Medea: ¿Por qué te dirigiste al inspirado ombligo de la tierra?

Creonte: por inquirir cómo lograr simiente de hijos.

Medea: ¡Por los dioses! ¿Has pasado tu vida, hasta hoy, sin hijos? (v. 670)

Estas dos escenas ubican el asesinato de los niños como parte de la venganza contra Jasón, pero sin duda fue el diálogo con éste el que influyó de manera significativa en dicha intención. En el verso 550, Jasón se defiende ante Medea argumentando que su nuevo matrimonio lo realizó teniendo siempre como fin un futuro provechoso para sus hijos.

\section{El deseo de Jasón}

Es reiterativa, en la tragedia que aquí revisamos, la idea del desamor de Jasón por sus hijos. Muy tempranamente aparece el pedagogo informándonos acerca de ello: 
Ciertamente su padre nos los ama, a causa de su matrimonio. (v. 88)

Afirmación que aparece también en boca de la nodriza (v. 82) y reiterada por Medea (v. 510):

Medea: pues el padre no se preocupa por procurar nada para sus hijos. (v. 342)

En caso de divorcio, los hijos pertenecían al padre, aunque Jasón no parecía muy interesado en ello. Al comienzo de la obra, él se encuentra en el palacio, gozando su nueva vida, y los niños están con el pedagogo; poco después, cuando Creonte ordena el exilio para Medea y sus hijos, Jasón no hace nada; incluso Medea le pide que interceda para que el rey le permita quedarse un tiempo más en tierra corintia, a lo que él accede sin sentir la menor preocupación por el futuro de sus descendientes.

Después enuncia, ante Medea, el discurso que condena a los niños:

Jasón: no, como te irrita, porque aborrezca tu lecho al haberme golpeado el deseo de una nueva esposa, ni porque tenga empeño en muchos hijos, pues no me quejo de los que he engendrado, sino, lo más importante, para que viviéramos bellamente y no careciéramos, sabiendo que al pobre lo evitaría todo aquel amigo; y educar a mis hijos a la manera digna de mi casa, y poner lazos hermanos a tus hijos, y enlazando la raza, ser felices. (v. 555)

Y continúa:

Jasón: ahora sabe bien esto: no por casarme a causa de una mujer, tengo ahora un matrimonio real, sino como dije, más bien para salvarte, y con el fin de procrear hijos soberanos del mismo linaje para mis hijos, baluarte de mi casa. (593)

Por ello, en el verso 791, la protagonista ratifica sus planes, incluyendo en ellos, por primera vez, el asesinato de los vástagos:

Medea: lamento qué acción será cometida después. Pues mataré a mis hijos. No hay nadie que me los arrebate.

Medea sólo tiene en la mente el daño que tal acto traerá a Jasón:

Coro: pero ¿te atreverás a matar tu semilla, mujer?

Medea: pues así sería herido enormemente mi marido. (v. 816)

Extrañamente, hacia el final de la obra, en el momento en que Jasón se entera de que su nueva esposa fue envenenada es cuando muestra interés en ellos:

Jasón: vine para salvar la vida de mis hijos, no sea que $m e^{7}$ les hagan algo los parientes. (v.1303)

Su preocupación tiene una razón: Jasón sabía que la oportunidad de procrear nuevos descendientes al interior de la casa real había desaparecido. Había que rescatar, entonces, a quienes antes había despreciado. $Y$ al verlos también perdidos, se lamenta, a lo cual Medea reprocha:

\footnotetext{
${ }^{7}$ Dativo de interés, cada vez más frecuente en la lengua castellana y que podríamos traducir como un "contra mí".
} 
Medea: ahora les hablas, ahora los amas, antes los despreciabas. (v. 1401)

Jasón había mostrado una gran indiferencia respecto de sus hijos, sin embargo, justifica su acción en nombre de ellos. Es a partir de que los vástagos son señalados como la motivación del padre para abandonar a Medea cuando se convierten también en la víctima perfecta contra el desleal marido. Así lo considera la infanticida, cuando empuña el arma mortal:

Medea: Ojalá sean dichosos, pero allí (en la muerte); pues aquí la felicidad se las quitó su padre. (v. 1073)

Medea ratifica, al final, en qué consiste este daño para Jasón:

Medea: En modo alguno lloras todavía. Espera a la vejez. (v. 1396)

\section{El deseo de Medea}

Si bien las palabras de otros contribuyeron o despertaron en Medea el deseo infanticida, ella también da evidencias del desinterés o desamor hacia los infantes. Por ejemplo, cuando enuncia una frase que revela el sentimiento, inconsciente tal vez, de aquellas mujeres que han pasado por la experiencia, muchas veces traumática, del parto:

Medea: que tres veces permaneciera junto al escudo que preferir parir un sola vez. (v. 250)

Y cuando Medea respondió a Jasón ÉTikTov autoús (etikton autus), una vez que éste le había preguntado la causa de tanto sufrimiento por la separación de sus hijos, su respuesta parece más bien un reclamo por el dolor del alumbramiento que una muestra de tristeza ante la posibilidad de perderlos:

Jasón: ¿por qué, por cierto, gimes tantos por estos niños?

Medea: yo los parí. (v. 929, cfr. v. 1241)

El coro, voz de las mujeres, comparte la experiencia de la descendencia ligada a la desdicha:

Coro: digo que cualquiera de los mortales que sea completamente inexperto en procrear hijos, aventaja en dicha a los que engendraron. (v. 1090)

Medea intenta justificar su acto homicida:

Medea: jamás sucederá esto: que entregue a mis hijos a los enemigos para que los ultrajen. Ciertamente es necesario que ellos mueran. $Y$ ya que es preciso, los mataremos nosotros ${ }^{8}$, pues nosotros los engendramos. (v. 1060)

\footnotetext{
${ }^{8}$ Este sujeto plural puede tratarse de un plural mayestático o de cortesía, o bien, puede hacer referencia, de manera indirecta, a lo que proponemos en este apartado: la muerte de los niños no es idea ni acción sólo de Medea, sino que intervienen otros -especialmente Jasón- con sus palabras y actos.
} 
E insiste más adelante:

Medea: amigas, la acción está decidida: después de matar a mis hijos, partiré de esta tierra rápidamente. Y no, por tardarme, los entregaré a mano más hostil para que los mate. Es necesario absolutamente que ellos mueran. $Y$ ya que es preciso, los mataremos nosotros, pues nosotros los engendramos. (v. 1236)

A pesar de los intentos de justificación de Medea, manifiesta de manera velada la otra razón por la cual el asesinato de los hijos era inminente. Al igual que el hombre, la mujer esperaba en su vejez gozar de los cuidados por parte de los hijos. En variadas ocasiones, Medea reprocha las penalidades que soportó por ellos, lamentando no poder recibir, creyendo al principio de la obra que se quedarían con el padre, el provecho esperado. $Y$ una vez enterada de que el decreto de exilio los incluía, se desvanecía también la posibilidad de los cuidados pertinentes en su vejez:

Medea: Inútilmente, pues, hijos, los crié, e inútilmente padecí y me quebranté con trabajos, soportando fuertes dolores en los partos. Verdaderamente tenía, desdichada, muchas esperanzas en ustedes, para sustentar mi vejez y, cuando muriera, que tendría buena sepultura son sus manos. [Trato] envidiable para los hombres. (v. 1029)

Por ello, resulta entendible, en su encuentro con Egeo, que Medea se lamente de la infertilidad del rey:

Medea: ¡Por los dioses! ¿Hasta ahora has vivido sin hijos? (v. 670).

Lo que tenemos aquí es un interés de tipo pragmático respecto de los hijos, la posibilidad de perder la recompensa esperada es otro elemento más que conduce a Medea a incluir a su descendencia en su plan de venganza.

Si se trataba de castigar, bien hubiera podido Medea conformarse con asesinar a la princesa y a su padre, o bien, a Jasón, pero no fue así. Es muy cierto que el plan garantizaba el sufrimiento eterno del desleal marido, lo cual con su muerte no hubiera sucedido. El plan es, en todos sentidos, genial. El motivo: quitar la posibilidad de trascendencia a Jasón, de perpetuación de su nombre, la posibilidad de recibir, en la vejez y a su muerte, los cuidados que todo griego esperaba. Medea no hubiera incluido en su plan de venganza la muerte de sus hijos, de no haber sido porque Jasón los colocó como motivo para su boda con la princesa.

Es el mismo Jasón quien, al hacerlos parte de su justificación, los coloca en la mira de Medea, en segundo lugar reafirma el rey Creonte, quien alude al cariño de su hija y, después, el rey Egeo, quien se lamenta de su problema de infertilidad y a quien Medea promete ayudar a cambio de asilo, y por último ella misma, que no observa en los hijos ningún sentido práctico.

Medea, para eliminar cualquier posibilidad de perpetuación, asesina también a la princesa, quien le garantizaba a Jasón linaje legítimo. La muerte del rey Creonte, 
aunque accidental, fue también merecida, pues éste fue quien determinó la boda de su hija con Jasón, además de que decretó el destierro de Medea sin que hubiera necesidad de ello.

En vez de asesinar también al traicionero marido, Medea encuentra la manera de hacerlo sufrir eternamente. Si Jasón la engañó con el pretexto de beneficiar a los hijos que había tenido con ella, tomarlos como instrumento para consumar su plan fue lo mejor forma que Medea podía haber encontrado.

Incluir la muerte de los hijos en la venganza no fue, pues, la idea de una persona, una individualidad, sino, de alguna manera, fue el producto de las condiciones sociales en las cuales la protagonista se encontraba inmersa y, en gran medida, las palabras de los otros reiteraron a la víctima de sacrificio.

No obstante, llegado el momento, Medea vacila entre cometer o no el infanticidio.

\section{El conflicto interno}

Es un acuerdo entre quienes analizan el infanticidio cometido por Medea que ocurre en ella una lucha interna, que para algunos es una batalla entre la razón y la pasión, 0 , para otros, entre un carácter masculino y uno femenino ${ }^{9}$. Entre los primeros, B. Snell afirma que existe en Medea una batalla psicológica entre la razón y la pasión donde esta última es la que domina, lo que conduce a la protagonista a cometer el infanticidio.

Por su parte, en su artículo Medea's Divided Self, H. Foley concluye que, en el famoso monólogo de Medea (vv. 1040-1080), se pone de manifiesto un conflicto entre la parte femenina, maternal del personaje y su lado heroico, masculino. De la misma opinión son A. Burnett y A. Dile. ${ }^{10}$

En el monólogo de Medea, ésta piensa que la mejor manera de castigar a Jasón es asesinando a sus hijos pero, por otro lado, la inocencia de ellos reaviva sus sentimientos maternales. Su lado femenino, maternal, le dificulta llevar a cabo el infanticidio, y la exhorta a olvidar los hechos y a marcharse llevándose con ella a los niños:

Medea: ¿qué haré? Pues mi corazón está perdido, mujeres, en cuanto he visto la mirada radiante de mis hijos. No seré capaz de hacerlo. ¡Adiós mis planes anteriores! Llevaré a mis hijos fuera del país. (v. 1044)

Y continúa deliberando:

\footnotetext{
${ }^{9}$ Los cuales, entendemos, son categorías sociales. Cfr. el artículo El hombre no es masculino y la mujer no existe de Luis Tamayo, en donde se cuestiona esta división entre lo masculino y femenino.

${ }^{10}$ Citados por Foley 1989, p. 62.
} 
Medea: Qué necesidad tengo yo, por dañar al padre con las desgracias de éstos, de ganarme yo misma desgracias dos veces más grandes? ¡No, yo no, desde luego! ¡No! ¡Adiós a mis proyectos! (v. 1045)

Pero pronto se alienta a continuar su plan olvidándose de ese "amor" de madre:

Medea: no te acobardes, ni te acuerdes de tus hijos: que son lo más amado, que los engendraste. Sino al menos durante este corto día, olvídate de ellos, y después gime. Pues si los matas, aun así, fueron por naturaleza queridos, y yo, una mujer desdichada. (v. 1250)

L. Galis (1992, pp. 65-81) avanza respecto a esta interpretación del conflicto interno e indica que el asesinato muestra el deseo de Medea de transformarse en héroe. En vista de que, abandonada por Jasón, no tiene modo de volver a su país, con su familia, se da cuenta de que está sola y, para lograr salir adelante, tiene que eliminar aquello que representa su vulnerabilidad, es decir, los atributos femeninos, cuya prueba más contundente son los hijos. En palabras de Snell: el triunfo de Medea no fue sobre sus adversarios sino sobre los profundos sentimientos maternales del héroe que tenía en sí. ${ }^{11}$

Esta interpretación indica de manera precisa el trasfondo del conflicto interno señalado por Snell, Burnett, Dihle y Foley. Lo que subyace detrás de esta escisión interna del personaje y que, por un aparte, la exhorta a conservar a sus hijos y, por otra, le ordena matarlos, es el deseo de todo héroe griego, es decir, el reconocimiento de los otros, donde lo fundamental es no quedar ante los demás como un sujeto burlado, sino como un héroe que decide tomar venganza ante la afrenta.

No obstante el plan racional que se percibe en la obra, los elementos que parecen justificarlo, y la batalla interna por la que pasa Medea, en todo crimen subyace lo que el psicoanálisis denomina "pasaje al acto", que reconoce un "más allá de la razón".

\section{El pasaje al acto}

Medea pudo haber tramado el asesinato de los niños como parte de su venganza, pero es algo muy distinto haberlo realizado. No es lo mismo imaginar una acción que llevarla a cabo. Ahora bien, ¿qué condujo a Medea a pasar de una mera idea al acto mismo del asesinato?

Medea reconoce que más allá de las razones que tiene para asesinar a sus hijos, su acto pertenece al ámbito de la irracionalidad:

Medea: los dioses y yo, insensata ${ }^{12}$, tramamos esto. (v. 1013)

Y el coro ubica el infanticidio cometido por Medea en el terreno de la locura:

Coro: he escuchado que antes, una, sólo una mujer puso su mano en sus hijos amados. Íno enloquecida ( $\mu$ aveíoav, maneisan) por los dioses. (v. 1282)

\footnotetext{
${ }_{11}^{11}$ Por Foley 1989, p. 63.

12 kakos fronous': literalmente "siendo sensato equivocadamente/mal"
} 
Efectivamente, el pasaje al acto, explica J. Allouch (1990, p. 360), es la realización de un acto derivado de la locura, el cual no tiene vuelta atrás, por ello, el pasaje al acto "no comporta en su instante la presencia del sujeto", es decir, el que actúa reconoce un más allá de la razón -y de luchas internas-.

El pasaje al acto conlleva los elementos señalados como propios de la locura: la cólera, el narcisismo, la burla y la fama, donde lo que se busca es la restauración del honor.

\section{La cólera}

J. Pigeaud, en su libro La maladie de l'ame, hace, desde el punto de vista biológico, un análisis del infanticidio cometido por Medea, señalando simplemente que fue el temperamento particular de la protagonista el que la impulsó a cometer el crimen.

Una víscera inflamada, ligada a la presencia de una bilis amarilla, es la que domina a esta mujer, empujándola, biológicamente, a cometer el crimen:

La víscera llena de Medea va a desatar el torrente que trastorna todo, que se lleva todo, que arruina todo, tal como un océano que rompe su dique. (Pigeaud, 1989, p. 383)

El carácter colérico de la protagonista es señalado varias veces en la tragedia:

Nodriza: No es posible que mi señora mitigue su cólera (xódov, xólon) con cualquier nimiedad. (v. 171)

Y el Coro ansía que Medea pueda dejar atrás la ofensa:

Coro: ¡Ojalá depusiera su cólera (ópyav, organ). (v. 177)

Y más adelante, lo confirma el rey:

Creonte: Respecto a ti, la malhumorada e irritada contra tu marido, Medea, he ordenado que salgas desterrada de este país [...]. (v. 272) 325)

Medea misma, una vez que tiene claro que la muerte de sus hijos es parte del plan de venganza, señala:

Medea: comprendo qué desgracia estoy a punto de cometer, pero mi ira (thymos) es más fuerte que mis pensamientos. (v. 1078)

La cólera es un elemento que subyace en los actos de locura ("ira furor brevis

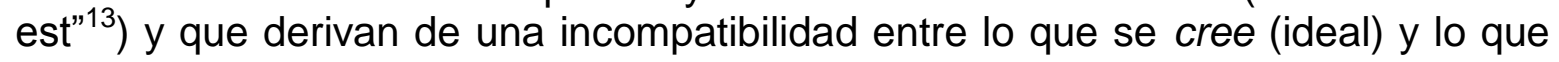
es (realidad), en donde, para decirlo en términos del héroe, se ofende al honor. En el seminario "El deseo y su interpretación", Lacan explica que:

[...] un afecto fundamental como la cólera no es otra cosa que esto: lo real llega de golpe [...] en el momento en que nosotros hemos hecho una muy bella trama

\footnotetext{
${ }^{13}$ Horacio, Epístola 2.
} 
simbólica, o todo va muy bien, el orden, la ley, nuestro mérito y nuestra buena voluntad. Uno se da cuenta, de golpe, de que las clavijas no encajan en los pequeños agujeros (Lacan, Seminario Le désir et son interpretation (1958-1959), inédito).

Medea era la concubina y tenía hijos bastardos con Jasón, pero eso no le había preocupado ni le ocasionaba conflicto, pues vivía en la creencia de tener el amor o por lo menos la lealtad de Jasón (basada en los juramentos), hasta que éste la enfrentó a su realidad al casarse con otra mujer para buscar un mejor futuro para él y para su hijos. La cólera se apoderó de Medea, motivándola a cometer la venganza, y así restaurar el honor dañado.

\section{El narcisismo}

En su ensayo titulado Consideraciones psicoanalíticas sobre un caso de Paranoia descrito autobiográficamente (Caso Schreber), Freud retoma - tomando como referencia la historia griega de Narciso, joven que al ver su hermoso reflejo en el estanque no se pudo separar de él y murió- la definición que del narcisismo había elaborado Havellock Ellis en su tratado sobre las perversiones: "El sujeto se toma a sí mismo, a su propio cuerpo, como objeto de amor" (Freud 1912, p. 60). En la Introducción del narcisismo, Freud amplía la definición anterior sosteniendo que el narcisismo no se encuentra solamente restringido a la estructura perversa y plantea que constituye tan sólo una forma de elección de objeto.

Por su parte, desde el inicio de sus enseñanzas, Lacan hizo del narcisismo una noción central para la comprensión de la locura. Llega a decir, incluso, que el núcleo de toda locura es precisamente el narcisismo, dado que conmina al sujeto a colocarse en una posición imposible, una en la que mediante su voluntad domina al mundo y que sólo espera recibir del otro reconocimiento, e incluso, reverencia (Lacan, 1953-54, p. 125). Un sujeto tal se vive como el centro de atención del mundo, y nada hay más molesto para él que la sola idea de ver disminuido su poder, mediante la real o imaginaria burla o indiferencia de los demás.

\section{La burla}

El héroe, en la Antigüedad, actuaba de acuerdo a un código de honor. Era lo que lo distinguía como tal. Por ello molesta tanto a Medea la idea de que sus adversarios se burlen de ella y no reciban castigo:

Medea: (...) ninguno de ellos atormentará contento mi corazón. (v. 398)

El elemento de la burla se manifiesta en todo momento en Medea:

Medea: no es soportable ser objeto de risa de los enemigos, amigas. (v. 797)

Este deseo de evitar la burla de sus adversarios es la manifestación, según la lectura de Foley, de una cultura de la vergüenza (1989, p. 65): 
Medea: tú, después de haber ultrajado mi lecho, no ibas a llevar una vida agradable, después de burlarte de mí. (v. 1354)

El miedo a recibir la burla la obliga a vencer el sentimiento maternal que sentía, y que la hacía dudar en su plan:

Medea: pero ¿qué me sucede? ¿quiero ser motivo de irrisión, dejando a mis enemigos sin castigo? (v. 1049; cfr. v. 1356)

Sabe que no es cualquier mujer, pues recuerda su identidad pasada de princesa, y del mismo modo que hace un personaje épico, se vanagloria de su raza, y se convence a sí misma de sus orígenes:

Medea: no es forzoso que te condenes a la burla por las bodas de la descendiente de Sísifo con Jasón, habiendo nacido tú de noble padre y siendo descendiente del Sol. (v. 406)

Cualquier otra mujer hubiera aceptado el hecho de que su marido contrajera nuevas nupcias más provechosas, pero Medea no había sido cualquiera, ella nació siendo princesa y descendiente de un dios, eso tenía que ser reconocido.

\section{La fama}

El máximo anhelo de reconocimiento o de la fama es propio del ser humano:

Jasón: Que no tuviera oro en mi casa, ni cantara una melodía más bella que la de Orfeo si no hubiera para mí un destino insigne. (v. 543)

Medea tenía que dejar atrás la devaluación a la que la fue sometida por Jasón y por la sociedad corintia, dejar atrás lo que la resonancia de su nombre le decía, que era nadie. Las alusiones a la fama como motivadora del infanticidio son constantes en la tragedia:

Medea: (soy) terrible con mis enemigos y benévola con mis amigos. Pues la vida de tales personas es famosa. (v. 807; cf. v. 234)

Y el Coro de mujeres la apoya - al principio - en su venganza contra Jasón, pues Medea representa con su actitud ante la afrenta el deseo de las mujeres:

Coro: los rumores convertirán en renombrada mi forma de ser, el honor llega a la raza femenina. La fama siniestra ya no alcanzará a las mujeres. (v. 418)

Medea sufría, tal como un héroe, de un narcisismo donde el honor es prioritario, donde lo que importa es el reconocimiento. En palabras de Foley, Medea intenta recuperar su condición heroica, que la caracterizaba en otro tiempo; desea vivir su identidad como hija de nobles antepasados (1989, p.76). Para reivindicar su nombre y ubicarse en un lugar temerario, la única forma que encontró fue matando a sus descendientes, acto que sólo pudo ser cometido en un gesto de locura. 


\section{Conclusión}

La etimología del nombre "Medea" coloca el infanticidio en el ámbito criminal, en el que la téxvn de la protagonista es esencial para llevarlo a cabo. Considerar el nombre "Medea" desde el punto de vista del significante nos conduce a otra interpretación de dicho infanticidio. Eurípides coloca en escena un evento que a todas vistas resulta monstruoso y, sin embargo, nos proporciona elementos que podrían exculpar a Medea. Nos muestra, por ejemplo, que sus hijos no se encontraban en una situación favorable por ser bastardos y que, si hubieran permanecido con su padre, de todas formas, ella no gozaría de los beneficios a los que su descendencia estaba obligada. El hecho de elegir a los hijos como víctima en su venganza lo indica la misma Medea: representaba la forma más efectiva de hacer sufrir a Jasón, pues sin ellos éste no podría gozar de los privilegios de una vejez y muerte con los cuidados que todo griego esperaba. Sin embargo, lo que produjo el pasaje al acto no fue sólo la suma de las circunstancias albergadas en la resonancia del nombre "Medea" sino, fundamentalmente, el narcisismo irracional que Medea padecía y que coloca al infanticidio en el terreno de la locura.

\section{BIBLIOGRAFÍA}

\section{Fuentes}

ARISTÓTELES. Ética Nicomaquea. México, UNAM, 1983. 1991.

Poética, traducción de Ángel Cappelletti, Caracas, Monte Ávila editores, EURÍPIDES, Medea. London, Oxford University Press, 1973 (ed. Alan Elliot).

- Medea. Torino, Societá editrice internazionale, 1938 (comentario de Angelo Taccone).

— Tragedias. México, REI, 1993 (ed. Juan Antonio López Férez).

- Théâtre complet 2. Paris, Garner-Flammarion, 1965.

HOMERO, Odisea. México, REI, 1992.

\section{Estudios}

ALFORD, Fred. "The psychoanalytic theory of Greek Tragedy en American Journal of Philology. Vol. 115, No. 3, 1994. 
ALLOUCH, Jean. 2/3 ocurrencias con Jacques Lacan. SITESA, México, 1992

-- Marguerite ou l'Aimée de Lacan. Paris. EPEL, 1990.

BACHOFEN, Johann Jakob, Mitología arcaica y derecho materno. Barcelona, Anthropos, 1988.

BENVENISTE, Emile. Problemas de lingüística general. México, SXXI, 1974.

BERISTÁIN, Helena. Diccionario de retórica y poética. México, Porrúa, 1985.

-- Alusión, referencialidad, intertextualidad. México, UNAM, 1996.

BETTINI, Maurizio. Lo straniero. Ovvero l'identità culturale a confronto. Roma, Gius, 1992.

BLAKE TYRRELL, William. Las amazonas. México, FCE, 1989.

CALASSO, Roberto, Las bodas de Cadmo y Harmonía, Anagrama, Barcelona, 2000

CAMERON, Averil et Amèlie Kuhrt (edits). Images of Women in Antiquity. Detroit, Wayne State university Press, 1993.

CANTÚ CORRO, José. La mujer a través de los siglos. México, Imprenta Acción moderna mercantil, 1938.

CELAN, Paul. Amapola y memoria. Madrid, Hiperión. 1981.

CLERC, Michel. Les meteques atheniens. New York, Arno, 1979.

CONSTANTOPOULOS, Michel. La tragédie de l'inconscient. Paris, Arcanes, 1995.

COOLE, Diana H. Women in political theory. Brighton, Sussex, Wheatsheaf books Ltd, 1988.

DUBY, Georges. (ed.) Historia de las mujeres. Madrid. Taurus, 1991.

EASTERLING, P. E. "The infanticide in Euripides' 'Medea" en Classical studies. Vol. XXV, Cambridge, 1977.

FERICGLA, Josep M. Envejecer. Barcelona, Anthropos, 1992.

FESTUGIÈRE, A.J. L'essence de la tragédie grecque. Paris, Aubier-Montainge, 1969.

FLACELIÈRE, Robert. Love in Ancient Greece. New York, Crown Publishers, 1962.

FOLEY, Helene. "Medea's Divided Self" en Classical Antiquity, Vol. 8, No. 1, California, 1989.

FREUD, Sigmund. Obras Completas. Vol. I, Bs. As. Amorrortu, 1976.

-- Vol. XV-XVI, Bs. A. Amorrortu, 1978.

-- Vol. II, Bs. As. Amorrortu, 1980.

GAGNEPAIN, Jean. Les noms grecs en -os et en-a. Paris, C. Klincksieck, 1959.

GALIS, Leon, "Medea's metamorphosis" en Eranos, XC, 1992. 
GASTELUM, Bernardo. El Sino de la Mujer. México, Imprenta Mundial, 1934.

GAUTHIER, Philippe. Symbola. Les étrangers et la justice. Paris, Nancy, 1972.

GIL FERNÁNDEZ, Luis. "La épica helenística”, en Estudios sobre el mundo helenístico, Universidad de Sevilla, Anales de la Universidad Hispalense. Serie: Filosofía y Letras, No. 8, 1971.

GLOTZ, Gustave. Ėtudes sociales et juridiques sur l'antiquité grecque. Paris, Hachette, 1906.

-- La ciudad griega. México, UTEHA, 1957.

GRIMAL, Pierre, Diccionario de mitología griega y romana. Barcelona, Bs. As., México, Paidós, 1986.

HARDWICK, Lorna. "Ancient amazons-heroes, outsiders or women? En Greece \& Rome, Vol. XXXVII, No. 1, Oxford, 1990.

JAKOBSON, Roman. Essais de linguistique générale. Paris, Minuit, 1963.

JAEGER, Werner. Paideia. México, FCE, 1989.

JUST, Roger. Women in Athenian Law and Life. New York, Routledge, 1989.

KNOX, Bernard. Word and action. Essays on the Ancient Theater. London, The John Hopkins University Press, 1979.

LACAN, Jacques. Seminario Les Ecrits techniques de Freud. (1953-1954) inédito.

-- Seminario de La identificación. (1960-1961) inédito.

-- Ecrits, Paris, Seuil, 1966.

-- Seminario Le Sinthome. (1976-1977) inédito.

-- La familia. Bs. As. Argonauta, 1978.

-- De psicosis paranoica en su relación con la personalidad. México, SXXI, 1983.

LACEY, Walter. The family in classical Greece. Ithaca, New York, Cornell University Press, 1989.

LICHT, Hans. Vida sexual de la antigua Grecia. Madrid. Ediciones Felmar (Abraxas), 1976.

LIDDELL, Henry. (comp.) Greek English Lexicon. Oxford, Clarendon Press, 1968.

MACDOWELL, Douglas. The law in classical Athens. Ithaca, New York, Cornell University Press, 1991.

MEZZABOTTA, M.R. "Jason and Orpheus - Euripides 'Medea', Verse 543" en American Journal of Philology, Vol. 115, No. 1-2, 1994.

MORENILLA, Carmen (edición crítica), Medea de Juan Alfonso Gil Albors, Universitat De Valencia, Valencia, 2001.

MOSSÉ, Claude. La mujer en la Grecia clásica. Madrid, Nerea, 1991.

MURRAY, Gilbert. Eurípides y su tiempo. México, FCE, 1966. 
PADEL, Ruth, A quien los dioses destruyen, México, Sexto piso, 2005.

PIGEAUD, Jackie. La maladie de l'ame, Paris, Les Belles Lettres, 1989.

POWELL, Anton. Euripides. Women and sexuality. London, Routledge, 1990.

RODRÍGUEZ ADRADOS, Francisco. Fiesta, comedia y tragedia. Barcelona, Planet, 1972.

ROMILLY, Jacqueline de. La tragédie grecque. Paris, Presses universitaires de France, 1973.

ROSSI, Amato, Donne, prostituzione e immoralità nel mondo greco e romano. Roma, Lucarini, 1979.

RUIZ, Elisa. La mujer y el amor en Menandro. Barcelona, El Albir, 1981.

TABOADA, Herná. "En torno a las Amazonas: mito, etnografía, utopía y mujeres" en Nova Tellus 8, México, UNAM, 1990.

TAMAYO, Luis. La temporalidad del psicoanálisis. México, Universidad de Guadalajara, colección Fin de Milenio, 1989.

- "El hombre no es masculino y la mujer no existe" en Caminos a la equidad, Año VII, No. 1, agosto de 2008, AAPA/UAEMex.

VERNANT, Jean Pierre. Mito y tragedia en la Grecia antigua. Madrid, Taurus, 1987.

VILTARD, Mayette. Action du publique dans le psychanalyse. Littoral 17, Toulouse, Eres, 1985. 